\title{
Analisis Faktor yang Mempengaruhi Terjadinya Penyakit Dermatitis di Wilayah Kerja Puskesmas Kecamatan Hiri Tahun 2020
}

\section{Sri Rahayu Utami' ${ }^{1}$ Nani Supriyatni ${ }^{2 \bowtie}$ dan $^{\text {Andiani }}{ }^{2}$}

${ }^{1}$ Mahasiswa Peminatan Epidemiologi Fakultas Ilmu Kesehatan, Universitas Muhammadiyah Maluku Utara. Ternate. Indonesia,

Email : srirahayu@gmail.com

${ }^{2}$ Staf Pengajar Fakultas Ilmu Kesehatan, Universitas Muhammadiyah Maluku Utara. Ternate. Indonesia,

Email : naniskm@yahoo.com, andianimahbub@gmail.com,

${ }^{凶}$ Korespondensi : $\quad$ Nani Supriyatni, Universitas Muhammadiyah Maluku Utara, Ternate, Indonesia, Email : naniskm@yahoo.com

\begin{abstract}
ABSTRAK
Dermatitis merupakan salah satu penyakit kulit yang disebabkan oleh peradangan dan iritasi hingga menyebabkan kulit terasa gatal (NIH, 2019). Penyakit ini ditandai dengan hadirnya kemerahan, pembengkakan, hingga pengerasan permukaan kulit. Peradangan dermatitis biasanya disebabkan oleh adanya kontak langsung zat kimia. Tujuan penelitian ini adalah untuk mengetahui Analisis Faktor Yang Mempengaruhi Terjadinya Penyakit Dermatitis Di Wilayah Kerja Puskesmas Kecamatan Hiri Tahun 2020. Jenis penelitian yang digunakan yaitu observasional dengan pendekatan case control study. Populasi dalam penelitian ini adalah masyarakat yang menderita Dermatitis diwilayah kerja puskesmas Kecamatan Pulau Hiri tahun 2020 dengan jumlah 281 kunjungan. Sampel dalam penenelitian ini sebanyak 106 responden, yang di peroleh dengan mengunakan metode observasional dengan pendekatan case control study. Hasil analisis dalam penelitian ini didapatkan bahwa ada hubungan pengetahuan responden dengan kejadian penyakit Dermatitis $(0,000)$, tidak ada hubungan antara suhu dengan terjaidnya penyakit Dermatitis $(0,697)$, ada hubungan antara kelembapan dengan kejadian penyakit dermatitis $(0,001)$, ada hubungan antara personil hygene dengan kejadian penyakit dermatitis di wilayah kerja puskesmas pulau hiri $(0,000)$. Di harapkan bagi peneliti selanjutnya dapat mengembangkan penelitian ini dengan variabel yang berbeda dan jumlah sampel yang lebih besar dengan selalu memperhatikan kesalahan- kesalahan agar dapat menginformasikan yang belum terjawab pada penelitian sebelumnya.
\end{abstract}

Keyword: Dermatitis, pulau hiri, analisis

Keanekaragaman dan Distribusi Ikan Gelodok (Mudskipper) Terkait Kondisi Fisik-Kimia Perairan Estuari Sungai Kumbe 
Daerah estuaria merupakan suatu komunitas campuran dari organisme air tawar dan laut. Sungai Kumbe merupakan salah satu sungai yang terdapat pada Kabupaten Merauke, dimana merupakan salah satu daerah yang kondisi daerah estuarinya masih alami. Penelitian ini bertujuan mengetahui keanekaragaman dan distribusi dari ikan gelodok (Mudskipper) serta kondisi fisik-kimia perairan estuaria di Sungai Kumbe. Analisis data yang digunakan data ekologi dan Indeks Morisita dengan melakukan analisis parameter kimia dilaboratorium. Hasil penelitian menunjukan komposisi jenis ikan gelodok yang ditemukan pada daerah pengamatan adalah Boleophthalmus boddarti sebanyak 52 species, Boleophthalmus pectinirostis sebanyak 38 species dan Periophthalmus takita sebanyak 19 species. Indeks keanekaragaman ikan gelodok berkisar anatara 1,292-1,573 sehingga termaksud kriteria keanekaragamn sedang sedangkan pola distribusinya besifat seragam pada kedua stasiun pengamatan di perairan estuaria Sungai Kumbe. Secara keseluruhan kondisi fisik-kimia perairan estuaria di Sungai Kumbe masih dalam kondisi baik untuk pertumbuhan organisme perairan.

\section{Pendahuluan}

Daerah estuaria merupakan suatu komunitas campuran dari organisme air tawar dan laut. Menurut Patty, (2008) distribusi ikan di ekosistem mangrove bervariasi secara temporal yang dipengaruhi oleh suhu air dan pasang surut. Huang et al., (2016) menambahkan bahwa pasang pH dan salinitas juga memberikan pengaruh yang signifikan terhadap kelimpahan ikan di kawasan mangrove. Biota yang hidup di daerah estuari adalah yang mempunyai toleransi tinggi terhadap perubahan lingkungan yang besar, ditandai dengan jumlah jenis yang sedikit dan ukuran kelompok yang besar.

Sungai Kumbe merupakan salah satu sungai yang terdapat pada Kabupaten Merauke, dimana merupakan salah satu daerah yang kondisi daerah estuarinya masih alami. Masyarakat memanfaatkan daerah tersebut sebagai tempat mencari nafkah, dimana salah satu biota yang ada di daerah estuari adalah ikan gelodok (Mudskipper). Potensi ikan gelodok (Mudskipper) selain sebagai filter feeder, juga banyak dikonsumsi dan dijadikan ikan hias terutama di Negara Cina, Jepang dan Korea (Ravi dan Rajagopal, 2009). Menurut AlBehbehani dan Ebrahim (2010), ikan gelodok mampu bertahan di daerah pasang surut karena memiliki kemampuan bernapas melalui kulit tubuhnya dan lapisan di mulut serta kerongkonganya. Pada ekosistem mangrove oleh Muhtadi et al., (2016) menyebutkan bahwa gelodok (Mudskipper)) merupakan salah satu jenis ikan bioindikator diekosistem mangrove.

Penelitian tentang ikan Gelodok (Mudskipper) pada Kabupaten Merauke masih sangat sedikit diantaranya ; Sunarni (2013), Kajian Bioekologi dan Pengelolaan Ikan Gelodok (Boleophthalmus boddarti), Biodiversitas dan Kelimpahan Ikan Gelodok (Mudskipper) di daerah Intertidal Pantai Payumb oleh Sunarni dan Maturbogs (2017). Penelitian tentang Keanekaragaman dan Distribusi Ikan Gelodok (Mudskipper) terkait Kondisi Fisik-Kimia Perairan Estuaria di Sungai Kumbe belum pernah dilakukan. Melihat penelitian tersebut penting sebagai gambaran dalam pengelolaan dan pemanfaatan ikan Gelodok (Mudskipper) khususnya Kabupaten Merauke maka penelitian ini perlu dilakukan.

Penelitian ini bertujuan mengetahui keanekaragaman dan distribusi dari ikan gelodok (Mudskipper) serta kondisi fisik-kimia perairan estuaria di Sungai Kumbe.

\section{Metode Penelitian}

Penelitian ini telah dilaksanakan selama 3 bulan pada bulan Oktober sampai Desember tahun 2018, dengan lokasi penelitan pada daerah estuari Sungai Kumbe, Merauke. Penelitian dilakukan pada 2 stasiun penelitian berdasarkan perbedaan lingkungan kondisi lingkungan perairan.

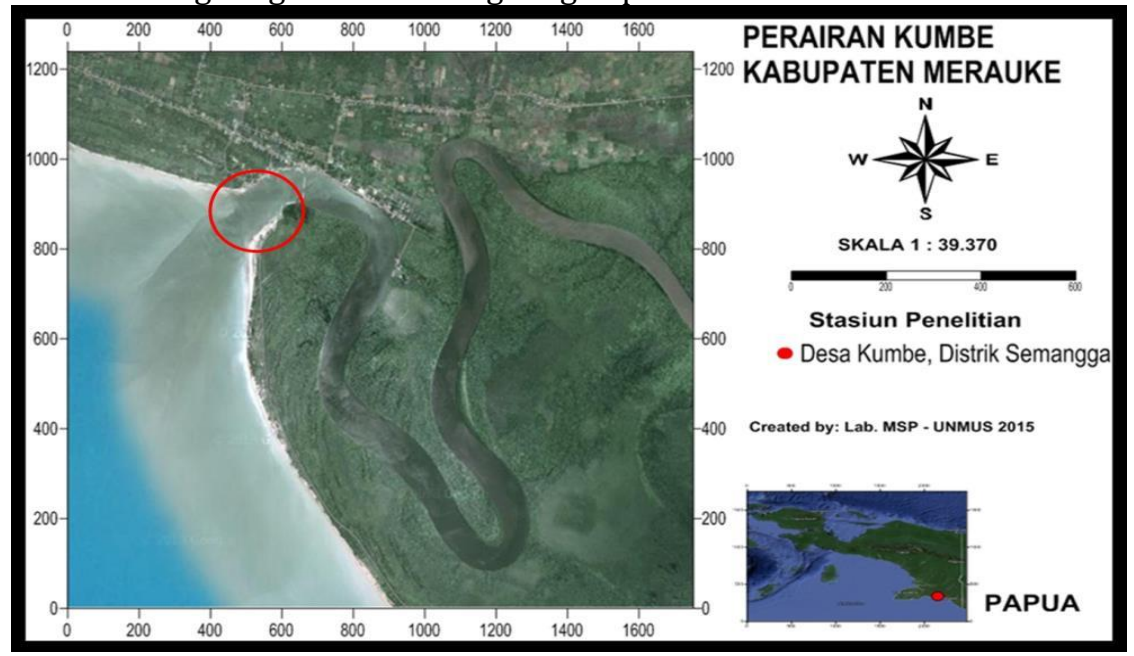

Gambar 1. Lokasi Penelitian 
Peralatan yang digunakan dalam penelitian adalah Global Positioning System (GPS), jala, perangkap, cool box, plastik sampel, botol sampel, kertas label, thermometer, $\mathrm{pH}$ meter air dan tanah, $\mathrm{DO}$ meter, $\mathrm{pH}$, handrefractometer penggaris, jangka sorong, stereform, alat tulis menulis untuk pencatatan data sampel sedangkan bahan yang digunakan dalam penelitian adalah formalin 40\%, alkohol $70 \%$ serta aquades.

Sampel ikan diperoleh dengan menangkap dengan menggunakan tangan di sepanjang aliran sungai kecil dan pesisir Pantai Kumbe. Pengambilan sampel dengan menggunakan tangan kosong dan tanpa alat dilakukan karena lebih praktis, cepat dalam pengambilan sampel dan juga penggunaan alat seperti serok ataupun jala. Pengambilan sampel dilakukan dengan metode purposive sampling disepanjang muara sungai. Sampel yang telah diperoleh kemudian diidentifikasi dan dianalisis di Laboratorium Manajemen Sumberdaya Perairan, Fakultas Pertanian, Universitas Musamus.

Analisis data yang digunakan antara lain, komposisi jenis, indeks keanekaragaman menurut ShanonWienner, Indeks Keseragaman, Indeks Dominansi, Untuk mengetahui sebaran (pola distribusi) ditentukan dengan menggunakan rumus Indeks Penyebaran Morisita (Krebs, 1989).

\section{Hasil dan Pembahasan}

Komposisi Jenis

Komposisi komunitas ikan dapat menunjukkan spesies yang mempunyai dominansi ekologis. Spesies yang dominan merupakan spesies yang mempunyai peranan yang jauh lebih besar terhadap komuniti dan lingkungannya. Hal ini dapat ditunjukkan melalui jumlah individu, ukuran, produksi dan aktivitas lainnya.

Tabel 1. Jumlah Ikan Yang Ditemukan Pada Tiap Stasiun

\begin{tabular}{cccc}
\hline Species & Stasiun I & Stasiun II & Jumlah \\
\hline Boleopthalmus pectinirostis & 19 & 19 & 38 \\
Periophtalmus takita & 2 & 17 & 19 \\
Boleopthalmus boddarti & 29 & 23 & 52 \\
\hline Jumlah & 50 & 59 & 109 \\
\hline
\end{tabular}

Berdasarkan hasil pengamatan selama penelitian, ditemukan 3 spesies yang paling banyak ditemukan pada daerah pengamatan adalah Boleophthalmus boddarti sebanyak 52 species pada kedua stasiun, kemudian species Boleophthalmus pectinirostis sebanyak 38 species dan Periophthalmus takita sebanyak 19 species.

Dari hasil pengamatan selama penelitian, jumlah keseluruhan species yang ditemukan sebanyak 109 species pada kedua stasiun. Pada stasiun I di temukan sebanyak 50 species sedangkan pada stasiun II ditemukan sebanyak 59 species. Berbedaan jumlah hasil tangkapan tersebut dapat diakibatkan pada stasiun I merupakan daerah pelabuhan penyeberangan yang aktivitas manusianya sangat banyak sedangkan pada stasiun II masih sangat alami.

Kelimpahan individu suatu spesies diartikan sebagai banyaknya individu tersebut yang terdapat dalam suatu area. Semakin tinggi atau besar nilai kelimpahannya berarti semakin banyak individu yang berada di daerah tersebut.

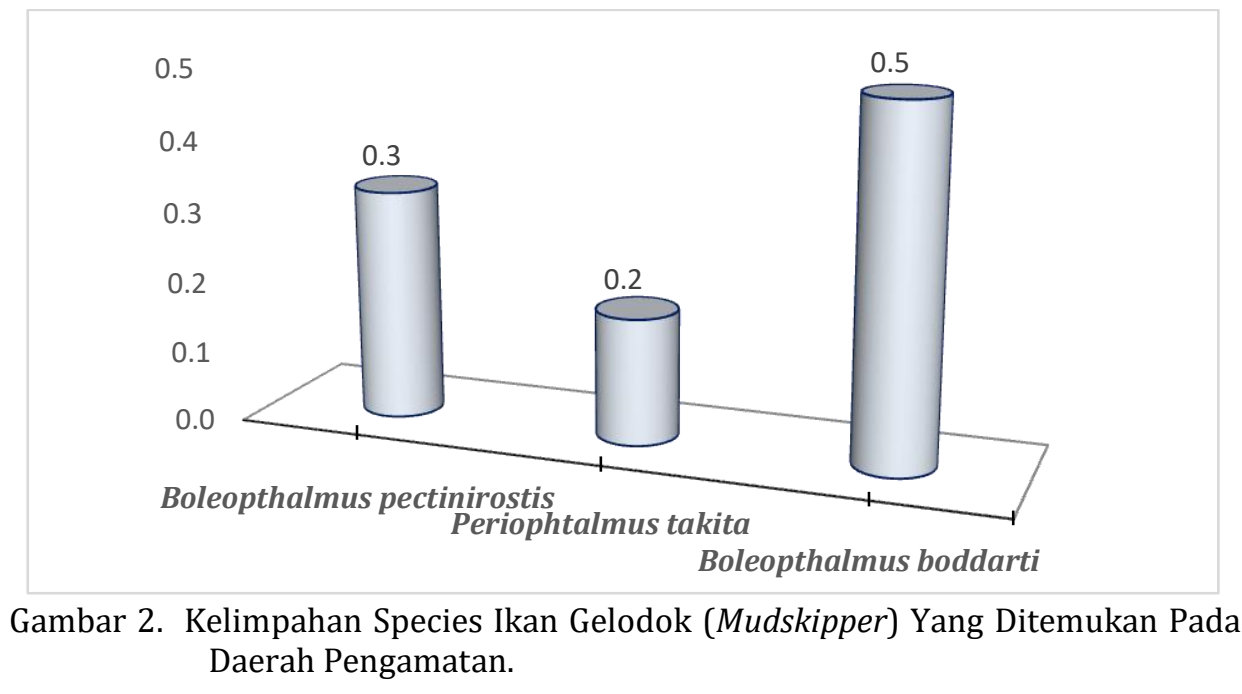

Berdasarkan hasil perhitungan indeks kelimpahan pada kedua stasiun, presentase tertinggi pada species Boleophthalmus boddarti sebesar 0,5 sedangkan kelimpahan terendah pada spcies Periopthalus takita sebesar 0,2 . Species 
Boleophthalmus boddarti memiliki kelimpahan tertinggi karena menyukai habitatnya pada daerah berlumpur yang banyak ditumbuhi oleh mangrove, dimana pada kedua stasiun banyak terdapat tumbuhan Mangrove. Jenis spesies Boleopthalmus boddarti ini memiliki adaptasi yang sangat tinggi, dimana apabila dia merasa terancam akan naik kedarat dan bersembunyi diantara pepohonan pantai. Pada musim dingin spesies ini membentuk pertahanan untuk menjaga genangan air, yang mendorong pertumbuhan diatom dan memungkinkan ikan terlibat aktifitas diatas permukaan. Ikan gelodok memiliki mata diatas kepala untuk bisa melihat kesegalah arah, sementara mulutnya mengarah kebawah untuk makan dipermukaan lumpur (Chen, et al., 2007). Species Periopthalus takita lebih menyukai zona intertidal , yang terdapat di air laut pada saat pasang tertinggi (Jaafar, et al., 2009).

Keanekaragaman, Keseragaman dan Dominansi

Keanekaragaman jenis, keseragaman dan dominansi merupakan indeks yang sering digunakan untuk mengevaluasi keadaan suatu lingkungan perairan berdasarkan kondisi biologinya. Suatu lingkungan yang stabil dicirikan oleh kondisi ekologis yang seimbang dan mengandung kehidupan yang beranekaragam tanpa ada suatu spesies yang mendominasi.

Tabel 2. Nilai Indeks Keanekaragaman, Keseragaman dan Dominansi Ikan Gelodok (Muskipper)

\begin{tabular}{ccc}
\hline Keterangan & Stasiun I & Stasiun II \\
\hline Keanekargaman (H') & 1,292 & 1,573 \\
\hline Keseragaman ( J') & 0,188 & 0,229 \\
\hline Dominansi (D') & 1,421 & 1,055 \\
\hline
\end{tabular}

Berdasarkan hasil analisis terhadap indeks keanekaragaman ikan gelodok pada stasiun I dengan presentase sebesar 1,292 sedangkan pada stasiun II diperoleh presentase sebesar 1,573. Nilai presentase kedua stasiun termasuk dalam kriteria sedang. Hal ini sesuai dengan kriteria nilai indeks Shannon-Wiener (Odum, 1993), yakni jika H’ kurang dari satu memiliki indeks keanekaragaman rendah, jika nilai H' lebih dari satu dan kurang dari tiga memiliki indeks keanekaragaman sedang dan jika nilai $\mathrm{H}^{\prime}$ lebih dari tiga memiliki indeks keanekaragam yang tinggi. Keanekaragaman jenis atau spesies merupakan karakteristik tingkatan dalam komunitas berdasarkan biologisnya, suatu komunitas dikatakan mempunyai keanekaragaman yang tinggi jika komunitas tersebut disusun oleh banyak spesies dengan kelimpahan spesies yang sama atau hampir sama. Indeks keseragaman jenis ikan gelodok pada stasiun I diperoleh presentase sebesar 0,188 sedangkan pada stasiun II diperoleh presentase sebesar 0,229, dengan demikian tingkat keseragaman ikan gelodok pada stasiun I dan Stasiun II masuk dalam kriteria tinggi. Indeks dominansi ikan gelodok pada stasiun I diperoleh 2,421 sedangkan pada stasiun II diperoleh 3,055. Nilai indeks dominansi lebih dari 1 berarti bahwa terdapat jenis ikan gelodok yang mendominasi. Nilai indeks dominansi sangat berkaitan dengan keseragaman,

\section{Parameter Lingkungan Perairan}

Tabel 3. Hasil Pengukuran Parameter Lingkungan Pada Daerah Pengamatan

\begin{tabular}{ccccccccc}
\hline No & $\begin{array}{c}\text { Kode } \\
\text { Contoh }\end{array}$ & pH & $\begin{array}{c}\text { Kekeruhan } \\
(\mathrm{NTU})\end{array}$ & $\begin{array}{c}\mathrm{DO} \\
(\mathrm{mg} / \mathrm{L})\end{array}$ & $\begin{array}{c}\mathrm{BOD} \\
(\mathrm{mg} / \mathrm{L})\end{array}$ & $\begin{array}{c}\mathrm{NO}_{3} \\
(\mathrm{mg} / \mathrm{L})\end{array}$ & $\begin{array}{c}\mathrm{PO}_{4} \\
(\mathrm{mg} / \mathrm{L})\end{array}$ & $\begin{array}{c}\mathrm{BOT} \\
(\mathrm{mg} / \mathrm{L})\end{array}$ \\
\hline 1 & ST.I & 7,27 & 396,33 & 5,13 & 2,17 & 0,23 & 0,06 & 47,40 \\
2 & ST.II & 7,28 & 189,00 & 5,49 & 1,70 & 0,30 & 0,03 & 42,77 \\
\hline
\end{tabular}

Dari hasil pengamatan parameter $\mathrm{pH}$ pada kedua stasiun terlihat tidak ada perbedaan yang signifikan yaitu berkisar antara 7,27-7,28. Romimohtarto dan Juwana (2007) menyatakan nilai pH yang ideal bagi kehidupan organisme air pada umumnya berkisar 6-9 sehingga dapat dikatakan pada kedua stasiun kondisi perairannya masih ideal untuk dapat hidup dan berkembang. Parameter kekeruhan berkisar antara 189,00396,33 NTU dan masih dalam kondisi baik. Parameter DO berkisar antara 5,13-5,49 mg/l, DO merupakan unsur yang paling penting bagi kehidupan biota laut karena oksigen tersebut digunakan untuk pernapasan, proses metabolisme, atau pertukaran zat yang kemudian menghasilkan energi untuk pertumbuhan dan perkembangbiakan. Nilai BOD berkisar antara 1,70-2,17 mg/l. Pada perairan alami memiliki nilai BOD 0,5-0,7 $\mathrm{mg} / \mathrm{l}$, BOD lebih dari $10 \mathrm{mg} / \mathrm{l}$ dianggap telah tercemar ( Jeffries dan Mills, 1996). $\mathrm{NO}_{3}$ berkisar antara 0,230,30mg/l dan $\mathrm{PO}_{4}$ berkisar antara 0,03-0,06 mg/l. BOT 42,77-47,40mg/l, kandungan bahan orgaik nya dalam kategori tinggi, dikarenakan kawasan mangrove kaya akan serasah mangrove dan adanya masukan nutrisi dari muara sungai disekitarnya. Berdasarkan hasil analisis laboratorium, kedua stasiun memiliki substrat liat. Pada kawasan mangrove substrat kategori berlumpur (liat) karena digunakan oleh ikan gelodok untuk membangun sarang yang digunakan unttuk dapat bertahan hidup dari predator, dan tempat bersembunyi pada saat perairan di sekirat mangove dalam kodisi pasang (Parendra, 2012). 


\section{Substrat}

Menurut Agusnar (2007), sedimen adalah padatan yang dapat langsung mengendap jika air didiamkan beberapa waktu.

Tabel 4. Hasil Analsis Substrat Pada Daerah Pengamatan

\begin{tabular}{cccccc}
\hline No & Stasiun & Pasir (\%) & Debu (\%) & Liat (\%) & Klas Tekstur \\
\hline 1 & 1 & 8 & 21 & 80 & Liat \\
2 & 2 & 8 & 21 & 80 & Liat \\
\hline
\end{tabular}

Berdasarkan hasil analisis pada kedua stasiun, kedua stasiun bersubstrat liat. Kehidupan organisme air ada juga ketergantungannya dengan bahan dan ukuran partikel dasar badan air. Dengan mengetahui bahan dasar dan ukuran partikel dasar perairan akan didapat informasi yang mungkin dapat menunjukkan tipe fauna yang hidup didasar badan air tersebut (Suin, 2002).

Pola penyebaran

Tabel 5. Pola Penyebaran Ikan Gelodok

\begin{tabular}{|c|c|c|}
\hline Keterangan & \multicolumn{2}{|c|}{ Pola Penyebaran } \\
\hline Stasiun & I & II \\
\hline Id & 0,467 & 0,324 \\
\hline Kriteria & Seragam & Seragam \\
\hline
\end{tabular}

Secara umum pola penyebaran ikan gelodok pada stasiun I dan stasiun II memiliki pola penyebaran yang seragam dimana nilai pola penyebarannya 0,467 dan 0,324 dengan demikian nilai Id $<1$. Menurut Pemborton dan Frey (1984); Tarumangke (1994), pola penyebaran yang seragam disebabkan oleh interaksi negative antar individu-individu, misalnya kompetisi terhadap makanan. Hal lain yang dapat mendukung pola seragamn tersebut karena kondisi lingkungan yang relatif sama dimana pada kedua stasiun penelitian ini merupakan daerah yang banyak terdapat ekosistem mangrove yang menyediakan banyak nutrisi atau makanan bagi ikan gelodok sehingga tidak menyebabkan terjadinya persaingan diantara spesies.

Menurut Suin (2002), faktor fisika, kimia dan biologi yang hampir merata pada suatu perairan serta ketersediaan makanan turut mempengaruhi orgnisme hidup pada habitatnya dan menentukan organisme tersebut hidup berkelompok, acak maupun seragam.

\section{Penutup}

1. Komposisi jenis yang ditemukan pada daerah pengamatan adalah Boleophthalmus boddarti sebanyak 52 species pada kedua stasiun, kemudian species Boleophthalmus pectinirostis sebanyak 38 species dan Periophthalmus takita sebanyak 19 species pada perairan estuaria Sungai Kumbe.

2. Indeks keanekaragaman ikan gelodok berkisar anatara 1,292-1,573 sehingga termaksud kriteria keanekaragamn sedang sedangkan pola distribusinya besifat seragam pada kedua stasiun pengamatan di perairan estuaria Sungai Kumbe.

3. Secara keseluruhan kondisi fisik-kimia perairan estuaria di Sungai Kumbe masih dalam kondisi baik untuk pertumbuhan organisme perairan

\section{Daftar Pustaka}

Al-behbehani , B.E dan H. M. A. Ebrahim. 2010. Enviromental Studies On The Mudskippers In The Intertidal Zone Of Kuwait Bay. Nature and Science. 8 : 79-87.

Chen S, Hong W, Zhang Q, Suy. 2007. Why Daes The mudskipper Boleophthalus Pectinirostris from Territories In Farming Ponds ? Journal Of Marine Biological Association Of The United Kingdom ; 87 : 615-619.

Huang, L.,D. Huang, Z. Wu, B. Kang, Z. Chen. 2016. Temporal variation of fish diversity and assemblages and their associations to environmental variables in the mangrove of Qinzhous Harbor, Guangxi Province, China. Turkish journal of Fisheris and Aquatic Science, 16 : 297-310.

Jaafar, Z., Perrig M and Chau, L.M. 2009. “Periopthalmus variabilitis ( Teleostei : Gobiidae : Oxudercinae), a valid species of Mudskippee, and a re diagnosis of Periopthalmus novemradiatus" Zoological Science 26 : 309 314.

Jeffries, M., dan D. Mills. 1996. Freshwater Ecology, Principles and Application. John Wiley and Sons. Chicester UK.

Muhtadi, A, S.F Ramadhani dan Yunasfi. (2016) Identifikasi dan Tipe Habitat Ikan Gelodok (Family : Gobiidae) di Pantai Bali Kabupaten Batu Bara Provinsi Sumantera Utara. Biospecies, 9 (2) : 1-6.

Odum, E.P. 1993. Dasar-Dasar Ekologi. Yogyakarta : UGM. 
Parendra, A. 2012. Gelodok, Si Ikan Unik Yang Lebih Suka Daratan . Online, http://Kompasiana.com/parendra89/gelodok-si-ikan-unik-yang-lebih-suka-daratan_550f14d681 33bc5fa4 Diakses 1 April 2017.

Ravi, V dan S. Rajagopal. 2009. Mudskipper Centre of Advenced Study In Marine Biology. Annamalai Universiti. 397-401.

Romimohtarto, K dan Juwana, S. 2007. Biologi Laut : Ilmu Pengetahuan Tentang Biologi Laut. Pusat Penelitian dan Pengembangan Oseanografi -LIPI. Jakarta. 402 hal.

Suin, N. M. (2002). Metode Ekologi. Padang: Universitas Andalas.

Sunarni. (2013). Kajian Bioekologi dan Pengelolaan Ikan Gelodok (Boleophthalmus boddarti). Tesis tidak dipublikasikan.

Sunarni dan M.R Maturbongs. 2017. Biodiversitas dan Kelimpahan Ikan Gelodok (Mudskipper) di daerah Intertidal Pantai Payumb, Merauke. Prosiding Seminar Nasional Kemaritiman dan Sumberdaya Pulau-Pulau Kecil, 1 (1) : 125-131.

Tarumangkeng, R. C. 1994. Dinamika Populasi Kajian Ekologi Kuantitatif. Jakarta : Pustaka Sinar Harapan.

Website:

Sumber, www. Fishbase.org. 